Journal of Agricultural Sciences
(Tarim Bilimleri Dergisi)

\title{
Increasing of Phenolic Compounds by Brassinosteroid Applications in Immobilized Cell Suspension Cultures of Vitis vinifera L. cv. Cinsault
}

\author{
Zehra BABALIK ${ }^{\text {a* }}$ (D)

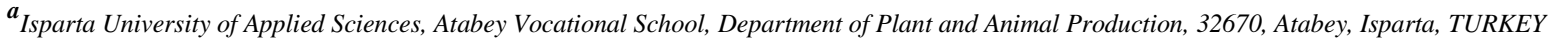 \\ ARTICLE INFO \\ Research Article \\ *Corresponding Author: Zehra BABALIK, E-mail: zehrababalik@isparta.edu.tr \\ Received: 14 January 2020, Revised: 23 March 2020, Accepted: 26 March 2020 / Online: 04 September 2021
}

\section{ABSTRACT}

In this paper, the effects on secondary metabolite accumulation of brassinosteroid (BR) (24-epibrassinolide (24-eBL) on immobilized cells that were obtained from Vitis vinifera cv. Cinsault was investigated. 24eBL was treated to immobilized cells covered calcium alginate beads at concentrations of $0,0.25,0.50,0.75$ and $1.0 \mathrm{mg} \mathrm{L}^{-1}$ for one month. As a result of this study, it was found that 24-eBL applications modified secondary metabolite accumulation and had positive effects on secondary metabolite production when the suitable concentration was used. While the highest total phenolic, catechin, $p$-coumaric acid and chlorogenic acid contents were found in immobilized cells treated $0.75 \mathrm{mg} \mathrm{L}^{-1} 24-\mathrm{eBL}$, the highest epicatechin, quercetin, trans-resveratrol contents were obtained in immobilized cells treated $0.50 \mathrm{mg} \mathrm{L}^{-1} 24-\mathrm{eBL}$ and the highest gallic acid content was determined in immobilized cells treated $0.25 \mathrm{mg} \mathrm{L}^{-1} 24$ eBL. Moreover, the highest 24-eBL concentration $\left(1 \mathrm{mg} \mathrm{L}^{-1}\right)$ decreased the content of secondary metabolite compared to the control $\left(0 \mathrm{mg} \mathrm{L}^{-1} 24-\right.$ eBL) except total phenolic and catechin content. To conclude, 0.50 and $0.75 \mathrm{mg} \mathrm{L}^{-1} 24-\mathrm{eBL}$ concentrations were the most suitable concentrations for immobilized cell culture to provide the highest secondary metabolite accumulation.

Keywords: 24-eBL, Immobilization, Grapevine, Phenolic compounds

(C) Ankara University, Faculty of Agriculture

\section{Introduction}

Phenolic compounds ranging from simple phenolic molecules to highly polymerized compounds, constitute major class of plant secondary metabolites (Dai \& Mumper 2010). Secondary metabolites are not correlated with photosynthesis, reproduction, respiration or other primary functions required for growth and development of the plants. Therefore, they have been considered waste products without significant use for plants for many years (Verpoorte 2013). However, nowadays, much attention has been devoted to secondary metabolites, due to they are valuable and important raw materials for many areas such as cosmetics, pharmaceuticals, antioxidants, insecticides and organoleptic properties of food industries (Keskin \& Kunter 2010; Pehlivan et al. 2016). Plants are grown at certain development stages under natural conditions in which they occupy small quantities and agricultural areas and the material required for obtaining secondary products is mostly achieved from plants collected from natural cultivation areas (Keskin \& Kunter 2008). The constant collection of some plant species from nature may come to the threat of extinction, it is difficult and expensive to collect some of them (Gonçalves \& Romano 2018; Karaboyacı \& Kılıç 2018). Furthermore, the amount and quality of secondary metabolites are influenced by climate conditions and the amount of the pure matters varies according to the quantity and quality of the plant material (Keskin \& Kunter 2010).

In recent years, several strategies have been developed to increase secondary metabolite production such as use of cell culture, selection of high productivity cell lines, media modification, permeabilization, nutrient and precursor feeding, plant cell immobilization, elicitation and biotransformation methods (Zhang et al. 2002; Murthy et al. 2014). By immobilization technique, plant cells are fixed to a suitable matrix such as agar, agarose, algae, calcium alginate, gelatine, and polyacrylamide in cell cultures (Pras \& Woenderbag 1999). However, alginate gels have received much attention due to their simplicity and relative lack of toxicity (Smetanska 2008; Nielsen et al. 2019). Since plant cells are very sensitive to chemical and physical stress, some biological and technological factors must be considered (Guardiola et al. 1996). In order to improve such processes and overcome the limitations of plant cell culture, immobilization has been considered as a tool for protecting cells against stress factors and enhancing the production of secondary metabolites (Choi et al. 1995). Elicitor applications are another effective strategy for secondary metabolite production in plant cell cultures (Shumakova et al. 2011). Elicitors affect the production of most commonly used secondary metabolites for stress tolerance and plant defense (Zhao et al. 2005). For this purpose Brassinosteroids (BRs), the sixth class of phytohormones could be used. BRs play diverse roles for physiological and developmental processes in plant growth and also respond to various biotic and abiotic stresses (Bajguz \& Hayat 2009, Ahammed et al. 2012). 24-eBL is the most 
effective and stable BR analog and has been found to high stimulatory effect in enzymatic activity and antioxidant systems in the majority of studies (Hayat et al. 2010). Moreover, 24-eBL also promote the production of secondary metabolites in several plants (Çoban \& Baydar 2017; Asci et al. 2019) and the exogenous application of BRs has been determined to increase antioxidant capacity and phenolic content in grapes (Luan et al. 2013; Xi et al. 2013; Ghorbani et al. 2017; Wang et al. 2019; Babalık et al. 2020). Although there are few studies conducted the impact of immobilization on the increased accumulation of secondary metabolites in several plants (Choi et al. 1995; Gillet et al. 2000; Dornenburg 2004) and grapevine (Iborra et al. 1994; Guardiola et al. 1996), there is no study to determine on the effect of brassinosteroid applications on phenolic contents of grapes in immobilized cultures. For this reason, more detailed studies are needed to investigate. This study was performed to provide a better understanding the effects of $24-\mathrm{eBL}$ and immobilized cells on the accumulation of phenolic compounds. This is also the first report to our knowledge of the use of $24-\mathrm{eBL}$ in immobilized cell culture in grapes.

\section{Material and Methods}

In the research, petioles belonging to Vitis vinifera $\mathrm{cv}$. Cinsault preferred in red wine making due to its low tannin and rich aromatic components, were used as plant material. Cuttings were provided from Tekirdağ Viticultural Research Institute. Single node cuttings were planted in pots containing sand, perlite and torf (1:1:1) and then incubated to a controlled environment chamber at $25^{\circ} \mathrm{C}$ with cool fluorescent daylight (16 h photoperiod). When 8-10 leaves were formed on the shoots, petioles were taken. Petioles were washed with tap water 3-5 times and then petioles were treated with $70 \%$ ethanol for $70 \mathrm{~s}$ under laminar airflow cabinet. After pretreatment with ethanol, petioles were rinsed with sterile distilled water for three times and surfacesterilized with commercial bleach $(22.5 \%)$ for $18 \mathrm{~min}$ and last rinsed with sterile distilled water again. Then, petioles were cut into $1 \mathrm{~cm}$ pieces and inoculated on MS medium (Murashige \& Skoog 1962) containing $1 \mathrm{mg} \mathrm{L}^{-1}$ benzylaminopurine (BAP) and $0.1 \mathrm{mg} \mathrm{L}^{-1}$ 2,4-dichlorophenoxyacetic acid (2,4-D), $30 \mathrm{~g} \mathrm{~L}^{-1}$ sucrose and $7 \mathrm{~g} \mathrm{~L}^{-1}$ agar. The pH of the medium was adjusted to 5.85 prior to autoclaving. Cultures were incubated at $25 \pm 1{ }^{\circ} \mathrm{C}$ under dark conditions. Calli were transferred to the same fresh media every 40-45 days in order to maintain adequate stock cultures.

\subsection{Immobilization of cells}

Approximately $1 \mathrm{~g}$ of cells from 25 days of callus cultures were mixed with $50 \mathrm{~mL}$ of $2 \%$ sodium alginate and $25 \mathrm{~mL}$ of liquid MS media containing $1 \mathrm{mg} \mathrm{L}^{-1}$ BAP, $0.1 \mathrm{mg} \mathrm{L}^{-1} 2,4-\mathrm{D}$ and $30 \mathrm{~g} \mathrm{~L}^{-1}$ sucrose. The cell/alginate suspension was then added drop by drop through a $5 \mathrm{~mL}$ pipette tip into $0.2 \mathrm{M} \mathrm{CaC1}_{2}$ solution, and almost homogeneous size beads $(\sim 4 \mathrm{~mm}$ in diameter) were formed. The beads were left to harden in $\mathrm{CaCl}_{2}$ solution for $30 \mathrm{~min}$ (Sajc et al. 1995), rinsed with sterile water and transferred into MS medium containing different concentrations of 24-eBL.

\subsection{Application of 24-eBL to immobilized cells}

Immobilized cells were added to $50 \mathrm{~mL}$ liquid MS nutrient media containing $1 \mathrm{mg} \mathrm{L}^{-1} \mathrm{BAP}, 0.1 \mathrm{mg} \mathrm{L}^{-1} 2,4-\mathrm{D}$ and $30 \mathrm{~g} \mathrm{~L}^{-1}$ sucrose with different concentrations of $24-\mathrm{eBL}\left(0,0.25,0.50,0.75\right.$ and $\left.1 \mathrm{mg} \mathrm{L}^{-1}\right)$. While choosing these concentrations, the previous study we made on vineyards (Babalık et al. 2020) is taken as reference. The 24-eBL stock solution was prepared by dissolving in dimethyl sulfoxide (DMSO). The immobilized cell cultures were incubated under dark conditions at $25 \pm 1{ }^{\circ} \mathrm{C}$ on the rotary shaker at $100 \mathrm{rpm}$ for one month. There were 3 replicates per treatment and 5 culture flasks (eg. erlenmayer) per replicates. At the end of the incubation, $1 \%$ sodium citric acid solution was added to the medium to dissolving calcium-alginate and they were incubated at $25^{\circ} \mathrm{C}$ for $30 \mathrm{~min}$. Then, free cells were washed with sterile water and dried in a $45^{\circ} \mathrm{C}$ oven until the constant mass is obtained.

\subsection{Extraction of phenolics compounds}

For extraction of phenolic compounds $0.1 \mathrm{~g}$ of powdered callus was extracted with $10 \mathrm{ml} 0.1 \% \mathrm{HCl}$ in $70 \%$ methanol. Extraction was ensured in the ultrasonic bath for $30 \mathrm{~min}$ and then centrifuged at $4000 \mathrm{rpm}$ for $15 \mathrm{~min}$. The residue left over from the first extract was washed with $\mathrm{HCl}$ :methanol solution once again and the supernatant was collected (it was done for three times total) and evaporated in a rotary evaporator at $45^{\circ} \mathrm{C}$ until dry.

\subsection{Determination of phenolic compounds}

Folin-Ciocalteu reagent assay was used to determine phenolic compounds (Singleton \& Rossi 1965). The absorbance was determined by spectrophotometer at $765 \mathrm{~nm}$. Results were expressed as mg gallic acid $100 \mathrm{~g}^{-1}$ dry weight (DW).

High-performance liquid chromatography (HPLC) analyses were performed according to the modified procedure of Caponio et al. (1999). Phenolic compounds were determined using the HPLC system including a pump (LC-10 ADvp), auto-sampler (SIL-10 ADvp), column oven (CTO 10Avp) and diode-array UV/VIS detector (DAD $\lambda_{\max }: 278$ ). The separation was performed on an Agilent Eclipse XDB-C18 (5 $\mu \mathrm{m}, 250$ x $4.60 \mathrm{~mm})$. Mobile phase A contained 3\% acetic acid in water; solvent B contained methanol. The gradient was: $93 \% \mathrm{~A}$ and $7 \% \mathrm{~B}$ for $0.01-0.10 \mathrm{~min}, 72 \% \mathrm{~A}$ and $28 \% \mathrm{~B}$ for $0.10-20 \mathrm{~min}, 75 \% \mathrm{~A}$ and $25 \% \mathrm{~B}$ for 20 $28 \mathrm{~min}, 70 \% \mathrm{~A}$ and $30 \% \mathrm{~B}$ for $28-35 \mathrm{~min}, 70 \% \mathrm{~A}$ and $30 \% \mathrm{~B}$ for $35-50 \mathrm{~min}, 67 \% \mathrm{~A}$ and $33 \% \mathrm{~B}$ for $50-60 \mathrm{~min}, 58 \% \mathrm{~A}$ and $42 \%$ 
B for $60-62 \mathrm{~min}, 50 \% \mathrm{~A}$ and $50 \% \mathrm{~B}$ for $70-73 \mathrm{~min}, 30 \% \mathrm{~A}$ and $70 \% \mathrm{~B}$ for $73-75 \mathrm{~min}, 20 \% \mathrm{~A}$ and $80 \% \mathrm{~B}$ for $75-80 \mathrm{~min}, 0 \% \mathrm{~A}$ and $100 \% \mathrm{~B}$ for $80-81 \mathrm{~min}, 93 \% \mathrm{~A}$ and $7 \% \mathrm{~B}$ for $81-90 \mathrm{~min}$. The flow rate was $0.8 \mathrm{~mL} \mathrm{~min}^{-1}$ and the injection volume was 20 $\mu \mathrm{L}$. Standard solutions, mobile phases, and samples were filtered through a $0.45 \mu \mathrm{m}$ pore size membrane filter. The detection UV wavelength was $278 \mathrm{~nm}$. The temperature of the column oven was $30^{\circ} \mathrm{C}$. Catechin, chlorogenic acid, epicatechin, gallic acid, $p$-coumaric acid, quercetin, and trans-resveratrol contents were expressed as $\mu \mathrm{g} \mathrm{g}^{-1} \mathrm{DW}$.

\subsection{Statistical analysis}

Descriptive statistics were presented as mean and standard deviation. Treatment effects were determined using one-way ANOVA. Duncan's multiple range test (significance level $\mathrm{p}<0.05$ ) was used to compare mean. All statistical analyses were conducted using the software package SPSS (ver:18).

\section{Results and Discussion}

Phenolic compounds changed significantly according to different concentrations of 24-eBL applications ( $\mathrm{p} \leq 0.05$ ). The results pointed out that the 24-eBL application caused an increase in phenolic compounds compared to control (Figure 1). As shown in Figure 1A, the highest total phenolic content was observed from the immobilized cells treated $0.75 \mathrm{mg} \mathrm{L}^{-1} 24-\mathrm{eBL}$, while the lowest values were recorded from the immobilized cells treated $1 \mathrm{mg} \mathrm{L}^{-1} 24-\mathrm{eBL}$. The amount of total phenolic compounds increased 1.9-fold compared to the control. Ahammed et al. (2013) stated that BR applications regulate secondary metabolism. 24-eBL has been reported to increase the activity of secondary metabolism-related enzymes such as phenylalanine ammonialyasethe first enzyme involved in flavonoid biosynthesis) and flavonoid 3-O-glucosyltransferase, which modulate the phenylpropanoid metabolism. Thus, it promotes the synthesis of phenolic compounds (Xi et al. 2013; Li et al. 2016). Asci et al. (2019) reported that exogenous applied BR acts as a signalling molecule to increase phenolic biosynthesis and enhances metabolite accumulation by affecting enzymes and genes involved in biosynthesis. In previous studies, it was found that BR applications increased total phenol and antioxidant capacity compared to control treatment (Xi et al. 2013; Ghorbani et al. 2017).

In our study, chlorogenic acid contents significantly changed depending on the applications. Based on the results, the highest chlorogenic acid was obtained the immobilized cells treated $0.5 \mathrm{mg} \mathrm{L}^{-1}$ 24-eBL, while the immobilized cells that treated $1 \mathrm{mg} \mathrm{L}^{-}$ ${ }^{1}$ 24-eBL application was the lowest (Figure 1C). Compared to the control, chlorogenic acid contents of immobilized cells treated $0.5 \mathrm{mg} \mathrm{L}^{-1}$ 24-eBL application increased 1.45-fold. 24-eBL applications had significant effects on the amount of catechin compared to control cells. The highest catechin accumulation was found in immobilized cells that treated $0.75 \mathrm{mg} \mathrm{\textrm {L } ^ { - 1 }} 24-\mathrm{eBL}$. However, control cells had the lowest values. Catechin content increased 4.76-fold compared to the control group (Figure 1B). Epicatechin content was ranged from 36.33 to $369.52 \mu \mathrm{g} \mathrm{g}^{-1}$. The concentration of $0.5 \mathrm{mg} \mathrm{L}^{-1}$ of 24 -eBL was given the highest epicatechin value. However, 24-eBL at higher concentration $\left(1 \mathrm{mg} \mathrm{L}^{-1}\right)$ caused a significant decline in epicatechin content. Epicatechin contents of immobilized cells treated with $0.5 \mathrm{mg} \mathrm{L}^{-1} 24$-eBL application increased 6.24-fold compared to the non treated 24-eBL cells (Figure 1D). The changes of gallic acid content in $V$. vinifera cv. Cinsault immobilized cell culture subjected 24-eBL application were also shown in Figure 1E. Gallic acid content was low in immobilized cells treated with $1 \mathrm{mg} \mathrm{L}^{-1} 24-$ eBL. The highest gallic acid content was found in the immobilized cells treated with $0.25 \mathrm{mg} \mathrm{L}^{-1} 24-\mathrm{eBL}^{\text {In }}$ this medium, the amount of gallic acid was 2.85 -fold higher than the control. The content of $p$-coumaric acid ranged from 2.23 to $15.30 \mu \mathrm{g} \mathrm{g}^{-1}$. According to data in Figure 1F, the highest amount of $p$-coumaric acid was obtained from the application of $0.75 \mathrm{mg} \mathrm{L}^{-1} 24-$ eBL. However, the lowest values were detected in $1 \mathrm{mg} \mathrm{L}^{-1} 24-\mathrm{eBL}$ application. The amount of $p$-coumaric acid increased 3.57fold over control. Quercetin contents significantly changed depending on the 24-eBL concentrations. The highest quercetin accumulation $\left(68.38 \mu \mathrm{g} \mathrm{g}^{-1}\right.$ ) was observed from $0.5 \mathrm{mg} \mathrm{L}^{-1} 24-\mathrm{eBL}$ application (Figure $\left.1 \mathrm{G}\right)$. There is currently no literature on the effects of BRs on catechin, chlorogenic acid, epicatechin, gallic acid and $p$-coumaric acid metabolism in grapevines, and therefore it is important to learn more to investigate the mechanism of action of BRs on grapes. This study was performed to eliminate the deficiency in the literature and to understand better the effects of BRs. It was also the first report determining the effects of BRs on catechin, chlorogenic acid, epicatechin, gallic acid and $p$-coumaric acid contents of grapes.

Immobilization is an effective method for enhancing secondary metabolite production in plant cell cultures. In this method agar, agarose, calcium alginate, gelatine, carrageenan or polyacrylamide are used as a matrix to fix plant cells (Pras \& Woenderbag 1999; Smetanska 2008). Gillet et al. (2000) stated that immobilized cells have created the formation of aggregate during the growth of cells, moreover, the presence of aggregates can modify cell to cell and cell to matrix interactions. Researchers also reported that synthesis of secondary metabolite could be stimulated as a result of increased gene expression due to cell-cell interaction in cells maintained in the culture medium.

Resveratrol is a phytoalexin that a stilbene derivative and has a potential protective role against cardiovascular disease. It is produced by plants and notably present in grapes (Bonnefont-Rousselot 2016). In the current research, the accumulation of the trans-resveratrol in immobilized cell cultures was changed according to the 24-eBL concentrations. The highest trans-resveratrol content $\left(16.37 \mu \mathrm{g} \mathrm{g}^{-1}\right)$ was recorded from the immobilized cells treated with $0.5 \mu \mathrm{g} \mathrm{g}^{-1} 24-\mathrm{eBL}$. In this medium, the amount of trans-resveratrol was 1.1-fold higher than the control (Figure $1 \mathrm{H})$. There is only one study conducted on the effects of exogenous brassinosteroid applications on trans-resveratrol in grapevine (Babalık et al. 2020). Researchers indicated that trans-resveratrol content increased 2.67-fold compared with control vines. The increase in trans-resveratrol accumulation through BR applications 
was thought to be result from the stimulating effects of BRs on the expression of genes encoding enzymes such as stilbene synthase that function in trans-resveratrol synthesis (Babalık et al. 2020). Keskin \& Kunter (2009) stated that in vitro techniques in grapevine, especially callus and cell suspension cultures, have several advantages to increase productivity in the production of trans-resveratrol. In this study, it was also deduced that callus cultures can be used as model systems for the stimulation and determination of trans-resveratrol production in grapevines.
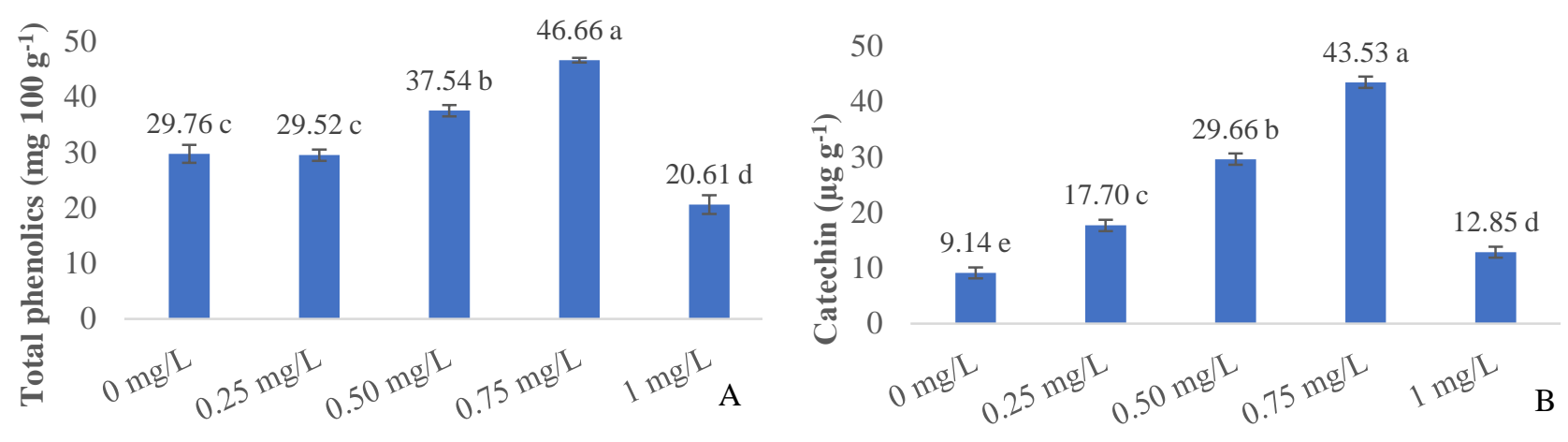

24-eBL applications
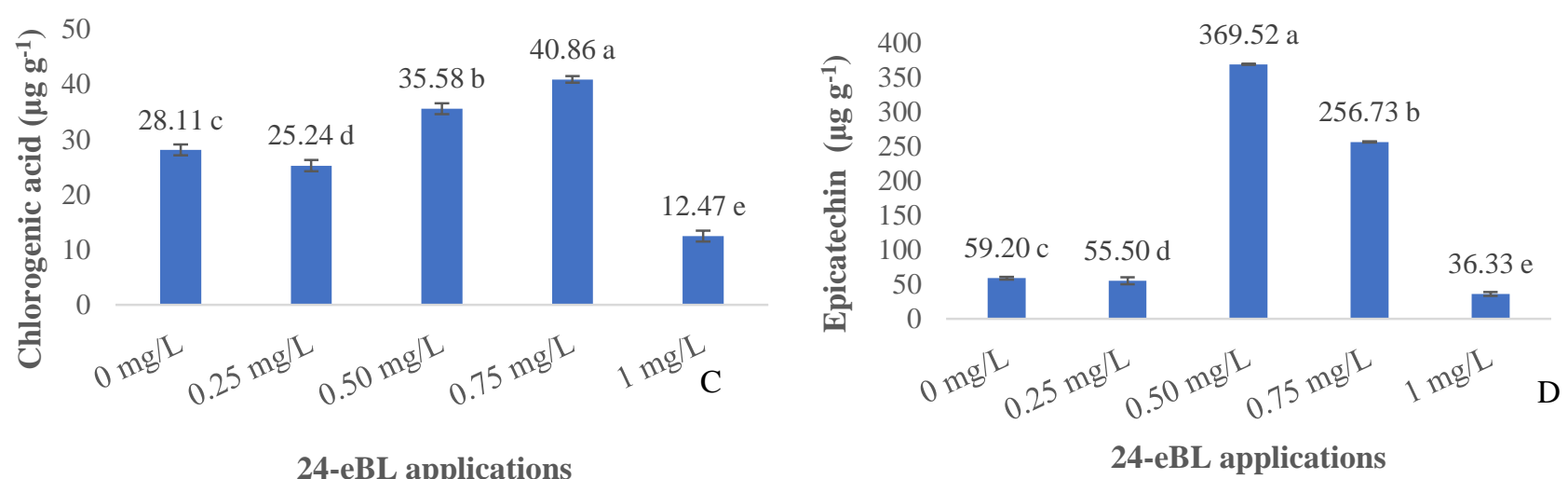

24-eBL applications
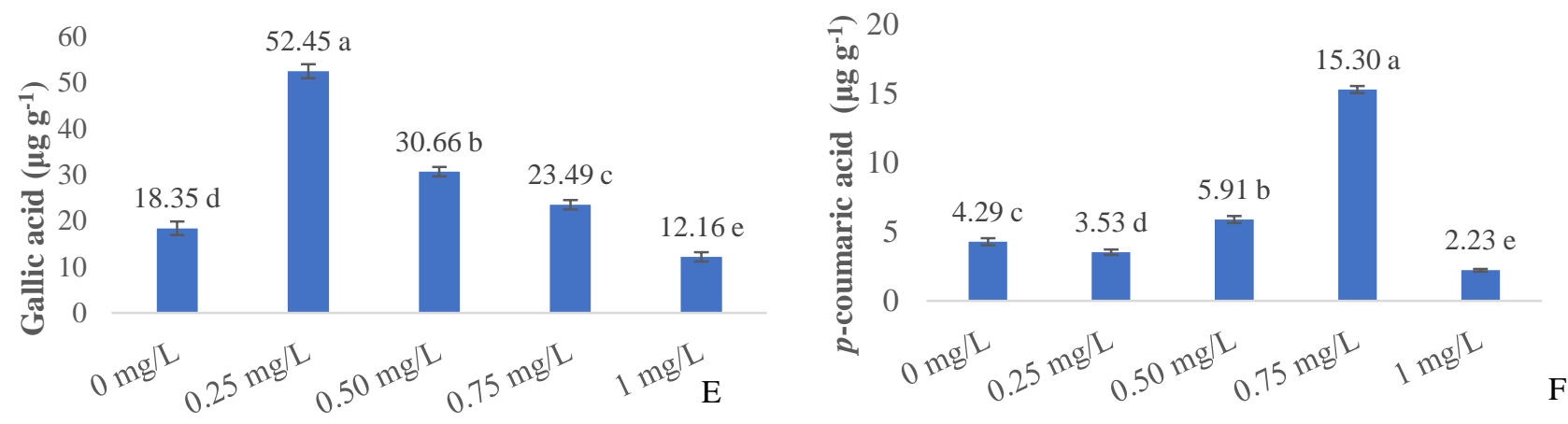

24-eBL applications

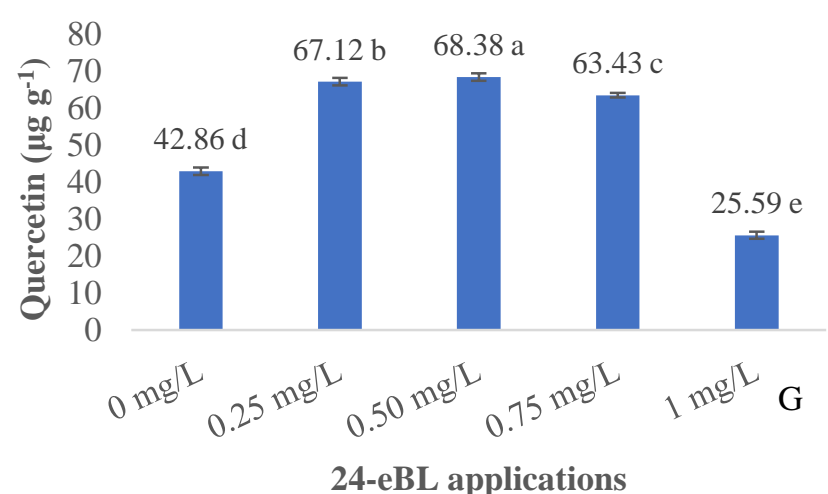

24-eBL applications

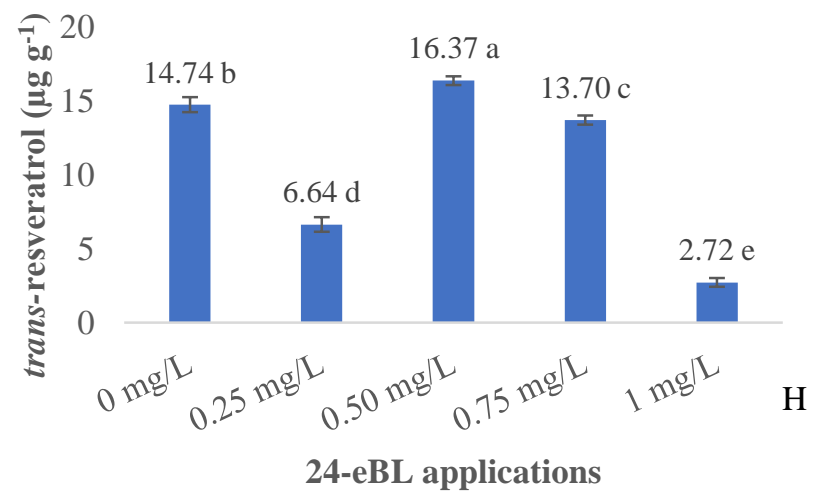

Figure-1. Effects of 24-eBL applications on the total phenolic content (A), catechin (B), chlorogenic acid (C), epicatechin (D), gallic acid (E), p-coumaric acid (F), quercetin (G) and trans-resveratrol (H) in Cinsault immobilized cells. Different letters indicate statistically significant differences among the applications $(\mathbf{p} \leq \mathbf{0 . 0 5})$ 


\section{Conclusions}

The present study demonstrated that 24-eBL application to immobilized cells has an advantageous effect on secondary metabolite production of cv. Cinsault, effectively. The best results were obtained from 24-eBL applications performed at concentrations of 0.5 or $0.75 \mathrm{mg} \mathrm{L}^{-1}$. However, it has been determined that the application of high concentrations of $24-\mathrm{eBL}\left(1 \mathrm{mg} \mathrm{L}^{-1}\right)$ reduced the secondary metabolite production even compared to control, because of this reason; higher doses of BR have been evaluated not effective.

\section{Acknowledgements}

I sincerely thank Prof. Dr. Nilgün Göktürk Baydar (Isparta University of Applied Sciences, Agricultural Science and Technology Faculty, Department of Agricultural Biotechnology) for providing technical support and laboratory facilities.

\section{References}

Ahammed G J, Yuan H L, Ogweno J O, Zhou Y H, Xia X J, Mao W H, Shi K \& Yu J Q (2012). Brassinosteroid alleviates phenanthrene and pyrene phytotoxicity by increasing detoxification activity and photosynthesis in tomato. Chemosphere 86: 546-555 https://doi.org/10.1016/j.chemosphere.2011.10.038

Ahammed G J, Zhou Y H, Xia X J, Mao W H, Shi K \&Yu J Q (2013). Brassinosteroid regulates secondary metabolism in tomato towards enhanced tolerance to phenanthrene. Biologia Plantarum 57: 154-158 https://doi.org/10.1007/s10535-012-0128-9

Asci Ö A, Deveci H, Erdeger A, Özdemir K N, Demirci T \& Baydar N G (2019). Brassinosteroids Promote Growth and Secondary Metabolite Production in Lavandin (Lavandula intermedia Emeric ex Loisel.). Journal of Essential Oil Bearing Plants, 22(1): 254-263 https://doi.org/10.1080/0972060x.2019.1585298

Babalık Z, Demirci T, Aşcı Ö A \& Baydar N G (2020). Brassinosteroids Modify Yield, Quality, and Antioxidant Components in Grapes (Vitis vinifera cv. Alphonse Lavallée). Journal of Plant Growth Regulation 39(1): 147-156 https://doi.org/10.1007/s00344-019-09970-5

Bajguz A \& Hayat S (2009). Effects of brassinosteroids on the plant responses to environmental stresses. Plant Physiology and Biochemistry 47: 1-8 https://doi.org/10.1016/j.plaphy.2008.10.002

Bonnefont-Rousselot D (2016). Resveratrol and cardiovascular diseases. Nutrients 8(5): 250. https://doi.org/10.3390/nu8050250

Caponio F, Alloggio V \& Gomes T (1999). Phenolic compounds of virgin olive oil: Influence of paste preparation techniques. Food Chemistry 64: 203-209 https://doi.org/10.1016/s0308-8146(98)00146-0

Choi H J, Tao B Y \& Okos M R (1995). Enhancement of secondary metabolite production by immobilized Gossypium arboreum cells. Biotechnology Progress 11(3): 306-311 https://doi.org/10.1021/bp00033a011

Çoban Ö \& Baydar N G (2017). Brassinosteroid modifies growth and essential oil production in peppermint (Mentha piperita L.). Journal of Plant Growth Regulation 36(1): 43-49 https://doi.org/10.1007/s00344-016-9614-1

Dai J \& Mumper R J (2010). Plant phenolics: extraction, analysis and their antioxidant and anticancer properties. Molecules 15(10): 73137352 https://doi.org/10.3390/molecules 15107313

Dornenburg H (2004). Evaluation of immobilization effects on metabolic activities and productivity in plant cells processes. Process Biochemistry 39: 1369-1375 https://doi.org/10.1016/s0032-9592(03)00262-0

Ghorbani P, Eshghi S \& Haghi H (2017). Effects of brassinosteroid (24-epibrassinolide) on yield and quality of grape (Vitis vinifera L.) Thompson Seedless. Vitis 56: 113-117

Gillet F, Roisin C, Fliniaux M A, Jacquin-Dubreuil A, Barbotin J N \& Nava-Saucedo J E (2000). Immobilization of Nicotiana tabacum plant cell suspensions within calcium alginate gel beads for the production of enhanced amounts of scopolin. Enzyme and Microbial Technology 26(2-4): 229-234 https://doi.org/10.1016/s0141-0229(99)00138-6

Gonçalves S \& Romano A (2018). Production of Plant Secondary Metabolites by Using Biotechnological Tools. In Secondary MetabolitesSources and Applications. IntechOpen. https://doi.org/10.5772/intechopen.76414

Guardiola J, Iborra J L, Rodenas L \& Canovas M (1996). Biotransformation from geraniol to nerol by immobilized grapevine cells ( $V$. vinifera). Applied Biochemistry and Biotechnology 56(2): 169-180 https://doi.org/10.1007/bf02786947

Hayat S, Yadav S, Ali B \& Ahmad A (2010). Interactive Effect of Nitric Oxide and Brassinosteroids on Photosynthesis and the Antioxidant System of Lycopersicon esculentum L. Russian Journal of Plant Physiology 57(2): 212-221 https://doi.org/10.1134/s1021443710020081

Iborra J L, Guardiola J, Montaner S, Canovas M \& Manjon A (1994). Enhanced accumulation of anthocyanins in Vitis vinifera cells immobilized in polyurethane foam. Enzyme and Microbial Technology 16(5): 416-419 https://doi.org/10.1016/0141-0229(94)90157-0

Karaboyacı Ö \& Kılıç S (2018). Bioengineering Methods in the Production, Development and Metabolism of Essential Oil in Plants. Bilge International Journal of Science and Technology Research 2: 1-9 https://doi.org/10.30516/bilgesci.491360

Keskin N \& Kunter B (2008). Production of trans-resveratrol in 'Cabernet Sauvignon' Vitis vinifera L cv. callus culture in response to ultraviolet-C irradiation. Vitis 47(4): 193-196 https://doi.org/10.15368/theses.2011.92

Keskin N \& Kunter B (2009). The Effects of callus age, UV irradiation and incubation time on trans-resveratrol production in grapevine callus culture. Tarim Bilimleri Dergisi 15(1): 9-13 https://doi.org/10.1501/tarimbil_0000001065

Keskin N \& Kunter B (2010). Production of trans-resveratrol in callus tissue of Öküzgözü (Vitis vinifera L.) in response to ultraviolet-C irradiation. The Journal of Animal and Plant Sciences 20(3): 197-200

Li X, Ahammed G J, Li Z X, Zhang L, Wei J P, Shen C, Han W Y (2016). Brassinosteroids improve quality of summer tea (Camellia sinensis L.) by balancing biosynthesis of polyphenols and amino acids. Frontiers in Plant Science 7: 1304. https://doi.org/10.3389/fpls.2016.01304

Luan L Y, Zhang Z W, Xi Z M, Huo S S \& Ma L N (2013). Brassinosteroids regulate anthocyanin biosynthesis in the ripening of grape berries. South African Journal of Enology and Viticulture 34(2): 196-203 https://doi.org/10.21548/34-2-1094

Murashige T \& Skoog F (1962). A revised medium for rapid growth and bio assays with tobacco tissue cultures. Physiologia plantarum 15(3): 473-497 https://doi.org/10.1111/j.1399-3054.1962.tb08052.x 
Murthy H N, Lee E J \& Paek K Y (2014). Production of secondary metabolites from cell and organ cultures: strategies and approaches for biomass improvement and metabolite accumulation. Plant Cell, Tissue and Organ Culture 118(1): 1-16 https://doi.org/10.1007/s11240014-0467-7

Nielsen E, Temporiti M E E \& Cella R (2019). Improvement of phytochemical production by plant cells and organ culture and by genetic engineering. Plant Cell Reports 38(10): 1199-1215 https://doi.org/10.1007/s00299-019-02415-z

Pehlivan E C, Kunter B, Daneshvar-Royandazagh S \& Keskin N (2016). Asma Hücrelerine Biyoteknolojik Bakış ve Yeni Çalışmalar. Bahçe 45 (Özel Say1): 805-811

Pras N \& Woerdenbag H J (1999). Production of Secondary Metabolites by Bioconversion, in Biotechnology: Secondary Metabolites, Ramawat, K. G. and Merillon, J. M., (Editors), Science Publisher, Inc., USA. https://doi.org/10.1201/b10756-11

Sajc L, Vunjak-Novakovic G, Grubisic D, Kovačević N, Vuković D \& Bugarski B (1995). Production of anthraquinones by immobilized Frangula alnus Mill. plant cells in a four-phase air-lift bioreactor. Applied Microbiology and Biotechnology 43(3): 416-423 https://doi.org/10.1007/bf00218443

Shumakova O A, Manyakhin A Y \& Kiselev K V (2011). Resveratrol content and expression of phenylalanine ammonia-lyase and stilbene synthase genes in cell cultures of Vitis amurensis treated with coumaric acid. Applied Biochemistry and Biotechnology 165: 1427-1436 https://doi.org/10.1007/s12010-011-9361-5

Singleton V L \& Rossi J R (1965). Colorimetry of total phenolics with phosphomolybdic phosphotungstic acid. The American Journal of Enology and Viticulture 16: 144-158

Smetanska I (2008). Production of secondary metabolites using plant cell cultures. In Food biotechnology (pp. 187-228) Springer, Berlin, Heidelberg. https://doi.org/10.1007/10_2008_103

Verpoorte R (2013). Secondary metabolites. In: Verpoorte R, Alfermann AW. (eds) Metabolic engineering of plant secondary metabolism. Springer Science-Business Media, pp. 1-31 https://doi.org/10.1007/978-94-015-9423-3

Wang Y T, Chen Z Y, Jiang Y, Duan B B \& Xi Z M (2019). Involvement of ABA and antioxidant system in brassinosteroid-induced water stress tolerance of grapevine (Vitis vinifera L.). Scientia Horticulturae 256: 108596 https://doi.org/10.1016/j.scienta.2019.108596

Xi Z M, Zhang Z W, Huo S S, Luan L Y, Gao X, Ma L N \& Fang Y L (2013). Regulating the secondary metabolism in grape berry using exogenous 24-epibrassinolide for enhanced phenolics content and antioxidant capacity. Food Chemistry 141(3): 3056-3065 https://doi.org/10.1016/j.foodchem.2013.05.137

Zhang W, Curtin C \& Franco C (2002). Towards manipulation of post-biosynthetic events in secondary metabolism of plant cell cultures. Enzyme and Microbial Technology 30(6): 688-696 https://doi.org/10.1016/s0141-0229(02)00041-8

Zhao J, Davis L C \& Verpoorte R (2005). Elicitor signal transduction leading to production of plant secondary metabolites. Biotechnology Advances 23: 283-333 https://doi.org/10.1016/j.biotechadv.2005.01.003

(C) 2021 by the authors. Licensee Ankara University, Faculty of Agriculture, Ankara, Turkey. This article is an open access article distributed under the terms and conditions of the Creative Commons Attribution (CC BY) license (http://creativecommons.org/licenses/by/4.0/). 